\section{A. E. Eruvbetine and Solo- mon Omatsola Azumurana}

A. E. Eruvbetine is a Professor of English at the University of Lagos,

Nigeria.

Email: eruvbetine@eruvbetine.com

Solomon Omatsola Azumurana teaches in the Department of English, University of Lagos, Nigeria.

Email: azumurana@yahoo.co.uk; sazumurana@unilag.edu.ng

\section{Melancholia and the search for the lost object in Farah's Maps}

\title{
Melancholia and the search for the lost object in Farah's Maps
}

Maps, given its intriguing narrative thrusts and multi-axial thematic concerns, is arguably the most studied or analysed of Nurrudin Farah's nine prose fictions. The novel's title as well as its synopsis has naturally dictated the focus of critics on the Western Somalia Liberation Front's war efforts geared towards liberating the Ogaden from Ethiopian suzerainty and restoring it to Somalia. The nationalist fervour, the war it precipitates and its fallouts of a strife-ridden milieu have such a pervading presence in the novel that the personal experiences of the novel's two major characters, Askar and Misra, are quite often discussed as basic allegories of ethnic and nationalistic rivalries. This paper focuses on the personal experiences of Farah's two major characters. It contends that the private story of Askar and Misra is so compelling and central to the many issues broached in the novel that it deserves significant critical attention. Drawing upon Sigmund Freud's and Melanie Klein's concepts of melancholia, the paper explores how central the characters' haunting sense of melancholia is to the happenings in Farah's Maps. Keywords: Freud, Klein, melancholia, lost object, Maps (Nurrudin Farah).

1

Although Maps is arguably the most studied or analyzed of Nurrudin Farah's nine prose fictions, the personal experiences of the novel's two major characters, Askar and Misra, are quite often discussed as basic allegories of ethnic and nationalistic rivalries. For example, Rhonda Cobham (83) in "Boundaries of the nation" investigates the correlation between "the ambiguity surrounding the gender assignation of the protagonist, Askar, and the uncertainties about the integrity of the boundaries that define the nation state, Somalia" within the context of how "the transformation of the anti-imperialist struggle in Africa into a nationalist movement exacerbated a crisis of individual and collective identity that is staged in the African novel." Derek Wright $(179,177)$ in "Parenting the nation" views Maps as a "fable of national identity" in which "nationality categories are mostly read through the positions assumed by the novel's various surrogate parents towards their charges." Also, in "Nation as a contested construct," Emmanuel Yaweh (45) insists that "Farah's Maps transgresses all kinds of boundaries — social, gender, generational, identity, and geographical — to show the idea of nation as having a shifting and unstable significance." The characters are therefore read as either complex symbols of national boundaries or representa- 
tives of territories or territorial conflicts; "Askar representing the Ogaden" in one vein and Misra being "much more precisely than Askar, the image of the Ogaden" in another (Wright 177, 179).

Francis Ngaboh-Smart (86), contending that Farah is a "cultural critic," maintains that

The "contradictions" inherent in the nationalist agenda, which most early African writers failed to question rigorously and which continue to affect the "reorganization" of post-independent nations, are urgent concerns in Farah's works [...] In short, the need to break with the belief in a univocal Somali identity or with the ethnic paradigm provides an important context for understanding Maps. (Ngaboh-Smart 86-7)

Ngaboh-Smart's use of psychoanalysis in the analysis of the relationship between Askar, the protagonist and Misra, his caretaker is slanted towards arriving at the conclusion that "through Misra's influence, Askar must also persistently draw on two cultural frames of reference, and he always puts two linguistic codes into practice: Somali and Amharic" (94). This conclusion reinforces his belief that Farah's work questions the univocal cultural assumptions of the fanatic Somali nationalists.

Another critic who has attempted reading this novel psychoanalytically is Michelle Lynn Brown (125) who in her essay entitled "Bleeding for the mother(land): Reading testimonial bodies in Nuruddin Farah's Maps" asserts that it "represents traumatic suffering in images of bodily illness and mutilation to signify hypochondriacal responses to the psychic violence that accompanies the physical violation wrought by neocolonialism." Brown's psychoanalytic critical lens captures the psychic violence wrought on the characters as a means of demonstrating the trauma of neocolonialism. In his own reading of Maps, Charles Sugnet, relating it to Tahar Ben Jelloun's The Sand Child, which he regards as a postmodern work, observes:

There are many points of connection between both The Sand Child and Maps: both describe the violent mapping of the body through practices like circumcision; both explore the movements from oral to written and the way culture writes the body; both expose the artifice of gender construction by following an ambiguous case of gender formation; and both are interested in the analogies and disjunctures between gender formation and the formation of national identity. (Sugnet 739)

Insisting that Farah's Maps is a nationalistic allegory, Sugnet (741) submits that "The sacred text that Maps so scandalously violates [...] is the sacred text of nationalism, with its mobilization of subjects for a triumphal linear progress toward national consolidation." Sugnet's emphasis on how the narrative style of Farah which destabilizes coherence and logicality, and which parallels the confusing or swopping of gender and national identity in ethnic self-determination, is in alignment with the views of Wright, Ngaboh-Smart, and Brown. They consider the contradictory narrative of 
the novel's events by the first, second and third person narrators as a stylistic device that projects the ambiguity associated with the formation of a gender and national identity. However, there is a psychological dimension, rooted specifically in the filial and familial experiences of the two major characters, to the shiftiness arising from the manner in which issues in the novel are unveiled.

2

In his attempt to make a distinction between mourning and melancholia, Sigmund Freud ("Mourning" 246) asserts that "[i]n mourning it is the world which has become poor and empty: in melancholia it is the ego self." And commenting on this assertion, David L. Eng (140) in his "Melancholia/Postcoloniality: Loss in The Floating Life" explains that "the turning of the loss object into the ego [...] marks a turning away from the external world of the social to the internal world of the psyche." It is this turning from the external to the internal world of the two main characters that previous readings of Farah's Maps have ignored. Rather than concentrating on the private experiences of the two characters, there has been an undue focus on their public experiences. In other words, rather than seeing the two characters first and foremost as products of their filial and familial experiences, they are largely seen as allegories of their conflict-ridden society.

The need to engage and present the psychological dimension to the actions and inactions of the two major characters in Farah's Maps seems to also have been provided by Uzoma Esonwanne (141) who observes that there has been "a yawning gap between psychoanalysis and African literature." In her observation:

Occasional forays notwithstanding, psychoanalysis and African literature have long maintained a studious, if not wary, distance from each other. As one might expect, the cost to both has been high: for psychoanalysis, the opportunity to actually establish its claims to providing a universal hermeneutics, especially by submitting key concepts (the subject, the unconscious, and so forth) and theoretical paradigms (Freud, Jung, Stein, Lacan, etc.) to rigorous scrutiny in the context of African literary works of art; for African literature, the opportunity not only to use psychoanalytic criticism but also to undertake a rigorous critique of psychoanalytic theories of the subject, sexuality and identity. (Esonwanne 140)

Although Esonwanne makes this observation in 2007, what she notes is still true presently. For most critics, African literature begins and ends with postcolonial criticism. Repeatedly, African literary critics appear to suggest and even insist that the reading of African literary texts cannot be effected without the application of Africanist or postcolonial theories. The result being that the universality of African literary texts is undermined. Thus, contrary to Esonwanne's observation, what a psychoanalytic reading of Farah's Maps would allow in the present interrogation is not so much the 
establishment of the claims of psychoanalysis "to providing a universal hermeneutics," as the need to establish the universality of African literary texts, as well as show how African characters are products of not just their sociological factors, but also their psychological complexes, which is rooted in their filial and familial experiences.

However, the psychological dimension that impacts on the main characters' actions and inactions as well as their lives and stories is melancholia; and this psychological condition essentially instigates their fantasy-driven search for a lost object/ ideal: a search that is central to the happenings in Farah's Maps. Sigmund Freud's "Mourning and melancholia" and Melanie Klein's "Mourning and its relation to manic-depressive states" provide valuable insight for understanding the nature of the two main characters' melancholia, how it is a product of their loss of valuable objects, how it propels their fantasized quests for the objects and how it colors their accounts or perceptions of events and incidents. As Judith Butler suggests, there is an affinity between Freud's and Klein's concept of melancholia. Like Freud, Klein's work on melancholia shows "how precisely what is lost, absent, or dead nevertheless becomes an object to conjure and sustain" (Butler 187). Also, Eva Tettenborn (103) notes that most theories on melancholia (including that of Klein) builds on Freud's approach. Yet, when L. Scott Lerner (45) in his "Mourning and subjectivity: From Bersani to Proust, Klein, and Freud" notes that "[i]n Klein, especially, and to a lesser extent in Freud, the 'spectral repetitions' seemingly critical to art in Proust are put forth as nothing short of a 'goal of normative development," he invariably articulates that Klein's postulations are an improvement on Freud's. As Amber Jacobs rightly observes:

Contemporary psychoanalytic object relations theory from Klein to Bion certainly positions the mother as central to the process of the psychic development of the child. The partially occluded mother in Freudian and Lacanian theory is resurrected and her power and significance in terms of the development of the infant is nowhere more fundamental than in the theories of the object-relation psychoanalytic tradition exemplified by Klein. (Jacobs 177-8)

While the aim of this essay is not to show the ways in which Klein's work on melancholia is differentiated or an improvement on Freud's, there is nevertheless the need to foreground why his and Klein's melancholia is being simultaneously deployed in this paper. As can be seen, Klein's work is seen as a feminist model of his work. Thus, Klein's work on melancholia is meant to make-up for any inadequacies or gaps, if there are any, in Freud's model. For Freud ("Mourning" 258, 243), however, "the three preconditions of melancholia [are] loss of the object, ambivalence, and regression of libido into the ego," while melancholia itself is "the reaction to the loss of a loved person, or [and] to the loss of some abstraction which has taken the place of one, such as one's country, liberty, an ideal." 
In Maps the two key characters' melancholic states emanate primarily from Askar's immediate loss of his mother soon after his birth and the earlier death of his father sometime before he was born, while Misra's results from her abandonment by her father as a child for not being a boy, as well as the death of her own son in his childhood. Their ambivalence is evident in their attitudes toward their lost object, which correlate with that of Klein's postulation that there is a conscious display of love which in most cases is not without an undercurrent of hate (100). Askar's love for his dead parents is unconsciously moderated by his feeling of their making him vulnerable through their absence while Misra's unconscious resentment of her desertion by her father and son is evident in spite of her fantasized love for them. This ambivalence is the source of the characters' internal "painful conflicts" and the attendant "conflict within the ego" in its "struggle over the object" (Klein 97; Freud, "Mourning" 258). This vacillation in emotional engagements with the lost object also makes it possible, at moments, in which reality prevails, for the libido to recoil from the lost object and regress into the ego. But this recoil and tension within splits the ego. The splinters complicate the emotional conditions of the characters as they experience reality and fantasy in different and sometimes conflicting ways (Freud, "Mourning" 254-8; Klein 95-8). Parts of the split ego become ego-selves which in Maps metamorphose into the three voices that tell the stories therein. Therefore, it is valid to ascribe the text's narrators to Askar's ambivalence-engendered ego-selves' voices that sometimes openly confess their inability to vouch for the authenticity of what they say.

These ego-selves which are only subtly present in the early chapters of the novel become more and more obvious as the story unfolds in non-sequential, highly intricate intermingling times, and ego-selves patterns. The ego-selves are loosely separated into childhood, adolescence and adulthood; they interact intricately in modes of tension-produced conscious and unconscious states in which love and hate, construction/destruction, reality and fantasy are in constant competition. In fact, Askar openly confirms the conflict of ego-selves within him when he is faced with the prospect of meeting Misra in Mogadiscio after she is accused of being a traitor. As one of his ego-selves or the second person narrator who Wright (176) describes as the "speculative second person" narrator reveals, you [Askar] began debating with the egos of which you were compounded, and, detaching itself from the other selves, there stood before you, substantial as a shadow, the self (in you) which did not at all approve of your touching or talking with Misra, lest you were lost in the intensity of her embrace. (Farah 60) Psychological tension has introduced multi-identities that are essentially inseparable from his personality into Askar's person as some of his ego identities serve as presenters of the narratives in the novel.

Askar seems born with melancholia while Misra's melancholia is as a result of multiple deprivations. Askar's mother dies soon after his birth, and his father had 
earlier died in a battle. He is brought up by a suspicious-indicted foster mother and experiences re-location from Kallafo to Mogadiscio as a unification war that temporarily seems to favour the ethnic nationalists, rages on. Misra, a father-rejected girlchild, displaced by, and made a war-loot in an earlier nationalist battle is destabilized by harrowing encounters and stampeded into surfacing in Kallafo to face further abuses. Their coming together set the stage for their fantasized searches for what have been taken from them-complicated searches in which, as the events in the novel unfold, the lost object takes on accretions of the loss of "one's country, liberty, an ideal" (Freud, "Mourning" 243) and makes what they seek to retrieve shifty and their chances of taking possession of it rather dicey.

Freud and Klein postulate a loss, which takes place initially in the later part of the oral and in the oedipal stages of child development. This loss which is associated with the mother's breast as a source of nutrient and later with the mother herself usually precipitates melancholia with its associated unease which Klein (111) terms the "depressive position." This condition recurs whenever unsettling events occur in life: "any pain caused by unhappy experiences, whatever its cause[...]reactivates the infantile depressive position" (Klein 111). In the novel the loss of a mother without the breast stage applies to Askar, while for Misra there is no loss of a mother but that of a father who refuses to assume responsibility for her. These losses lead to their melancholia and depressive positions that are usually recalled and reinforced whenever they have traumatic experiences.

Freud and Klein further maintain that the melancholic unease or depressive position is usually managed through a process of "reality testing" which may or may not be successful (Klein 86-7). Reality testing leads to a successful management of the depressive position when the external reality harmonizes with the internal, but the situation remains problematic if the external world ruffles the inner being. The characters in the novel have a difficult time managing their depressive positions as realities are haunted and sometimes overwhelmed by or mixed with fancies in their quests for the retrieval of lost objects. The lost object for each of them is complex and compounded. What begins as a loss of father for Misra, and that of mother for Askar, gradually and systematically (in conscious and not-so-conscious ways) expands and merges - in deeply personal ways - with ethnic, nationalistic, linguistic, narrative, gender and cultural identities that defy all attempts to establish a unifying centre. Thus Askar's and Misra's resolution-defying depressive positions remain, as their inner fantasies are constantly crushed by brutal realities.

Askar's and Misra's childhood losses virtually make them over to each other and convert their lives into ones in which their moods oscillate between sustained depressive positions and brief moments of elations dubbed "manic position" by Klein (100). Askar remains a partial replacement for Misra's lost Father and also perhaps for her dead son just as Misra as a foster parent for Askar becomes a substitute of 
some sort for his mother. Freud ("Mourning" 244) maintains that

Reality-testing has shown that the loved object no longer exists, and it proceeds to demand that all libido shall be withdrawn from its attachments to that object. This demand arouses understandable opposition - it is a matter of general observation that people never willingly abandon a libidinal position, not even, indeed, when a substitute is already beckoning to them. This opposition can be so intense that a turning away from reality takes place and a clinging to the object through the medium of a hallucinatory wishful psychosis.

The characters' denial of their losses, a psychological defence mechanism, prevents them from withdrawing their libido from the lost objects and enables them to indulge in fantasizing the objects, even as they interact with their substitutes. For example, Misra's relationship with Askar makes her conjure up an earlier attachment to her father whom she interacted with when she was barely five, fond of creating internal good objects and having yet to experience the full impact of rejection: "Not only did she see her father in you but also the child in herself [...] She sought her childhood in you and she hid her most treasured secrets which she was willing to impart to you and you alone. In you, too, she saw a princess, barely five, a pretty princess surrounded with servants and well-wishers." (Farah 7) What occurs is a temporary embracing of Askar as her "father" not as a substitute for what is lost but as what fires her fantasized re-living of an internalized glorious past that never really existed. Misra becomes a child again in the presence of Askar and she is transported on the wings of her imagination into her supposed childhood with a wealthy father who treated her like a princess. The reality test's negative result is temporarily ignored as she basks in the triumph of a moment of manic position.

Misra clings to her past "through the medium of hallucinatory wishful psychosis." Her father having been a noble/rich man accounts for her vision of herself as a childhood "princess-daughter." The setting in which the relationship between her and Askar takes place, being the family compound of Qorrax, is ideal for such hallucinatory visions. Insofar as Qorrax, in age and economic status, resembles Misra's "lost" father, he serves as a means of re-establishing some kind of spiritual bond with her unreachable father. Misra's fantasy-instigated equation of Askar with her father confers the status of adulthood and all its powers on him and this enables the second person narrator of the first chapter of Maps, who is psychologically an aspect of Askar's ego to state that "the moment (Askar) took (Misra's life) over" he exhibits the traits of an adult: he has "a stare" that penetrates the minds of adults, he does not like children's games,' he is considered an adult by Misra and Karin, and he communicates with Misra in the darkness of the night like an adult (Farah 8, 14).

Yet Askar remains a child who according to Misra "feels lost unless his outstretched hands brings back to his acute senses the reassuring message that I am [Misra is] touch- 
ingly there. He cannot imagine a world without my [Misra's] reassuring self" (Farah 12). Askar's simultaneous status as a child and a grown-up male is captured in the following passage:

She began walking with a slight stoop and her hip, as though ready to carry you, protruded to the side. She no longer saw as much of Aw-Adan, the priest, as she used to, a priest who used to teach her, on a daily basis a few suras of the Koran and in whom she was slightly interested. That interest deteriorated with the passage of the days and finally petered out the way light fades when there is no more paraffin in the lamp [...] She had had a "fatherless" child herself and the child had died a few months before you were born. She was sad she had had to feed you a bottle; she was sad she couldn't suckle you, offer you her own milk, her soul. (Farah 8-9)

Misra poses as a proud mother carrying Askar who somehow also fills the vacuum of her child's death but regrets being unable to breast feed him. Her diminished interest in Aw-Adan makes Askar a convenient alternative to him. Freud notes that, "Really we never can relinquish anything; we only exchange one thing for something else. When we appear to give something up, all we really do is to adopt a substitute" (Character and Culture 36). However, it is important to note that Misra's interest in her lover did not really peter out because although she calls Askar "my man" (Farah 5) and relates to him like a "lover," she openly admits that her Koranic teacher, "Aw-Adan is a man." She is visibly embarrassed when Askar seeks to know: "What about Uncle Quorrax? Is he a man too?" (Farah 27). This development sets Askar and Aw-Adan against each other as they compete to possess Misra exclusively in a Freudian Oedipal conflict that underscores Askar's melancholia and complicates and even confuses his search for the lost object.

Askar views Misra's lovers, especially Aw-Adan; who brutally hurts him in the Koranic school, as rivals for his mother's love. He has unconsciously equated them with his father and Misra with his mother at this stage. This development unconsciously generates in him an inner conflict or ambivalence, a hate/love complex for his parents that fuels his depressive position in his fantasized search for the lost object. Misra's sexual relationships with Aw-Adan, Uncle Qorrax and a secret lover are also, in many respects, related to her efforts to recapture the lost object, which is her father. While it does seem that she engages in these relationships to guarantee her stay in the family premises and perhaps secure a measure of material sustenance, her feeling of having some hold on the sexual partners and sometimes even the enjoyment of love making aptly demonstrate what Freud and Klein regard as an ambivalence towards the loved object: the sexual encounters simultaneously reveal her unconscious desire to recover paternal acceptance as well as an attempt to punish these men for her rejection by her biological father. Her illusionary vision of her father's love for her may have even entailed her father being oblivious of her 
being a girl child because the close bodily contact between Askar and Misra does at one level lead to gender fluidity for both characters.

Misra's "amorous association" with Askar's uncles simultaneously provides her with opportunities to unleash, in subtle ways, her pent-up feelings of disdain for her father and men like him. She shuns Aw-Adan's offer of marriage, asking him how sure he is that the child in her womb is his. She then opts for an abortion as a clear signal that she is unwilling to give birth to a child for any of her Somali bed-mates. One is tempted at this stage to ask who the father of the son she lost is and how the child died. Did she have a hand in the child's death for the same reason that she did opt for an abortion? Recall that her entry into the Kallafo community enables her to escape justice for the murder of the man who sought to marry her against her will. She seems to have some air of superiority as a foreigner which prevents her from accepting Aw-Adan; his speaking Amharic with her notwithstanding. In the light of this interpretation, her embracing Askar as a substitute for her dead son becomes suspect and the possibility of Askar being a "price-object" in furtherance of her search for her foreign lost object cannot be ruled out.

Misra's "hold" on these Ogaden men serves her well because it makes the community gloss over the fact that she is an alien in the Ogaden. She is not really willing to give up her Oromo/Amharic origin which for her is rolled into one with her lost object; her father as her being and identity are locked into this lost object. In fact, her having an Ethiopian lover when the Ogaden was suddenly lost to the Ethiopian forces and her name reversion to Misrat demonstrate her desire to hang on to the "superior" alien status which she believes her birth confers on her. This development makes her avowal of commitment to the Ogaden and its people during the war difficult to believe, and lends some measure of substance to the rife belief of her being a traitor. Moreover, it creates the basis for a re-examination of the kind of love she expends on Askar and the manner in which she brings him up.

The birth of Askar and the mother's tragedy provide Misra with an opportunity to strengthen her position in the community. She masterfully takes over the baby and the immediate history of its coming into the world. As one of the narrative voices puts it, Misra "by virtue of her foreignness, felt she had access to the Somali cosmos-if there is anything like that-through you [Askar]." (Farah 17) Misra's access to the Somali cosmos combines a sense of defiance with that of some power over the child's relations. Her retrieving Askar from her dead mother, cleaning him up and keeping the secret from the "community of relations" for "some sixteen or so hours" before divulging it (Farah 8) places her in a position of authority as a custodian of Askar and the only source of information on the circumstances of his birth. Moreover, Misra's act of taking total control over the circumstances of Askar's birth is capable of raising issues about her role in Askar's mother's death. No relation of Askar's dares raise these issues because Askar's parents are wanted by the Ethiopians 
and Askar himself has supposedly "chosen" to be with Misra. Misra maintains such a firm physical and psychological control over Askar from the time she makes him public to his family, that her shadow and what it entails haunts him all through his search for the lost object. She physically, intellectually and psychologically nurtures him: "She nourished you, not only on food paid for by a community of relations, but on a body of opinion totally her own" (Farah 10), a body of opinion replete with her "alien" lore with which she sows seeds of conflict, enables them grow and flourish within him [Askar], and divides his sense of self into parts, some of which become manifest as the he, you and I narrative postures of Maps. These three-selves of Askar engage in a troubled quest for the lost object (parents) in which his unified sense and feeling of selfhood and being is implicated. Askar, in this search, contends with haunting insecurity which Misra's versions of who his parents are entail: "She told you secrets about your parents no one else was willing to tell you" (Farah 7).

Askar seems to have inherited this feeling of insecurity which Misra reinforces. His exhibition of this trait, even in his infant contacts with Misra, constantly and continuously reverberates in different kinds of misgivings about the stability of his selfhood/identity/mission/lost object. The novel opens with these misgivings by the adult Askar: "And you question, challenge every thought that comes across your mind [...] You doubt, at times, if you exist outside your own thoughts, outside your own head or Misra's" (Farah 3). The origins of this skepticism are numerous in the opening pages of the novel which dwell on Misra's absorption of the baby Askar into her life and Askar's similar gesture towards Misra. In fact, the same narrative voice which claims that the "point of you [Askar] was that, in small and large ways, you determined what Misra's life would be like the moment you took it over" also does insist that "in small and large ways, Misra, now that you were hers, saw her own childhood 'as a category cradled in a bed of memories'" (Farah 8, 9). The two characters take over each other's life but, in the early stages of this interaction, Misra's action seems a deliberate one meant to enforce her "acceptability" by Askar's people while Askar's is rather instinctive or intuitive.

4

A child irrespective of its sex carries its mother inside him in Klein's theory. According to Steven Epstein (836) in his reading of object relations theory, "a practical unity can come to be forged-a socialized individual who carries that past history of object relationships inside."It is evident from the beginning of his encounter with Misra that Askar does have ingrained in him an intuitive sense, like a genetic code from his parents, or a feeling of diffidence which expresses itself through his contradictory reactions to Misra's motherliness; he seems to need the care and yet resents Misra's role and presence. The following passage illustrates Askar's infant melancholic ambivalence towards Misra's role and gestures: 
It was not long before you tasted in Misra's motherliness which reabsorbed you, a motherliness in whose tight, warm embrace you felt joyous one second, miserable the following instant. Again you would try to make contact and when she did her best to return it, you would appear startled and willing to withdra, you would shun any contact with her completely and move away. (Farah 5)

Askar's non-self-conscious being, which is "ecstatic" one moment and "pensively quiet" the next, reflects a resentment of Misra's foreignness, if not in terms of her being an "Ethiopian," at least in terms of her not being his biological mother. Commenting on Klein's assertion that “it is the ego's unconscious knowledge that the hate is indeed also there, as well as love," Butler (183) states that "Doubt then marks the vacillation between love and hate; it is the epistemic effect of ambivalence, and of the desire to annihilate that which one seeks to protect from any such annihilation." These instinctive vacillations gradually become more and more self-conscious as the events in the novel unfold in tandem with Askar's growth and maturation. This accounts for the subtle strain of mutual suspicion that marks the relationship between the two main characters from the beginning of events in the novel, the much remarked surface harmony notwithstanding. Moreover, this reaction sheds light on the differences and sometimes feud-separated or opposed lost objects of their quests.

The "alien" origin and air of Misra and the role they play in the community "pitch her against" Askar's mother and, in subtle ways, account for the characters' depressive positions and the attendant ambivalences that are discernible in their "taking over" each other. Virtually all facets of the interactions of these two characters are affected by an undercurrent of tensions that impact their quests for lost objects. Even the "bodily closeness" of Askar and Misra which Wright says "allows the motherless male child and the childless surrogate mother to live, complementarily, inside each other, [and] later resists the abstract intellectual hatreds of creed and country that are awakened by the Somali-Ethiopian War in the Ogaden"is not without tension as is evident when Wright (177) notes that "Askar's budding nationalism is grounded in the special stifling, suffocating intimacy generated by the one-parent-one-child family." It is obvious that not only does the bodily closeness of the two major characters fail in leading to the putting aside of "abstract intellectual hatreds of creed and country"; it does actually subtly promote them, as it does not seem strong enough to obliterate the connection between the lost parents/objects of Askar and the Somali nationalism that hardly appeals to Misra.

Misra is not unperturbed by their apparent inseparability since some of her actions inadvertently send Askar out of her world and make him move away from her and enable him to identify with his biological parents and their idealisms. For example, their sharing the same bed in which their bodily fluids intermingle is compounded by Askar's being uncomfortable with what goes on between Misra 
and her male bed-mates. In fact, there is an incident in which Askar's yelling aborts Misra's love encounters with one of his "uncles" that she really loved being with. Misra is so mad that she tells him "I hope you'll learn to be on your own like all other children of your own age'; or, her eyes misted with tears of anguish, 'I will kill you unless you behave yourself. I'll strangle you-so as to live my own life" (Farah 40). Misra desires her freedom and her threat to kill Askar, if the opportunity presents itself, need not be taken lightly, given her previous history and the unspeakable suspicion that Askar's mother may have been saved if Misra asked for help as soon as she noticed the mother's plight. Misra always wants to be what she is; one with a proud alien heritage, who enjoys the rights and privileges of a 'colonizer,' her so-called servant designation notwithstanding. It is important to note that Misra's bad temper and mood during her monthly periods do not ever elicit from her so strong a desire to eliminate her ward in order to live as she chose. Askar's loud yells can be regarded as a protest against Misra's mortgaging of their shared privacy or interpreted as resulting from his oedipal anxiety. Nevertheless, the protests serve as early signals of his distancing himself from Misra as he seeks to establish emotional/idealistic connection with his lost parents whose lives were dedicated to a cause that is opposed to what Misra represents in the Ogaden. Later in life, reviewing these "amorous" exploits of his foster mother with Uncle Hilaal, he concludes: "It was more like a mother who brought dishonor upon the head of his own child—right in his presence" (Farah 55). For him, there is no possibility of his biological mother dishonouring him even in his absence. These thoughts, in many ways, consciously and unconsciously compel his quest for self-definition/ actualization through the recovery of his lost objects [parents] that stand directly in antagonistic opposition to what his community of relations believe in what Misra stands for, a belief which Askar is somehow infected with. Askar also explicitly expresses how his desire to escape from his stifling closeness to Misra must of necessity entail his killing her, especially since whenever Misra is "fed up" with him she always says "You are on your own" (Farah 56, 58). He always feels destabilized whenever this statement is hurled at him because of the power of indispensability which it confers on Misra, a power similar to the colonial one tolerated by his people. Askar however revolts as the phrase is thrown at him for having wet his bed "when a little under five and a half years old" and as Misra attempts to leave him to his own designs, he tells her: "When I grow up and I am a man ... I will kill you ... To live, I will have to kill you" (Farah 59). Askar's declaration seems in consonance with the theories of Freud and Klein, which state that a boy child has to sever himself emotionally from his mother to achieve his independence. As Nancy Chodorow (qtd in Caputi 314) puts it, "Boys will respond differently to the internalized maternal [...] and masculinity will define itself in terms of difference and autonomy. Given the masculine search for separation and distinction, then, 
the oedipal phase among boys will arrive earlier and represent an attempt to truly leave behind the child's dependence on the mother."

Wright (178) also supports this view when he remarks that "As he grows up Askar feels a natural need to live a life independent of Misra and expresses the desire of each man to kill the 'mother' in him." Nevertheless, the context in which Askar makes this utterance is too complex to fit solely into an oedipal category. It is important to note that, even at this age, he is in contact with Karin whose care for him during Misra's periods is significant and he already appreciates Karin's husband, Armadios, who like his father "had a job to do" (Farah 77). He is aware that his mother died doing a job that necessitated his being born, and that his mother was buried, in secrecy. He is also deeply moved by Armadios' gift of the picture of Ernest Bevin.

Askar's circumcision symbolically thrusts on him the assertiveness of manhood which he feigns to call Misra to order at the age of five and a half and which he now deploys to prevent Misra from being sent away from the room they shared. He maintains that his use of this power is not in appreciation of his uncle's kind gesture of yielding to his will but in celebration of "how clever (he) was in making her return possible" (Farah 94). Interestingly, his having Misra with him really has very little to do with his attachment to her but as a demonstration of the fact that Misra "wasn't herself Somali and" her "psyche they (traditional taboos) wouldn't affect" (Farah 94). Her non-Somali status is obvious to him even as he ceases to share the same bed with her, making his quest for freedom through the attainment of a distinct Somali identity inseparable from his attempts to retrieve his lost objects. He continues to work towards this goal through acts like that of heroically enduring Aw-Awdan's savage beatings, participating actively in the masculine pranks of boys of his age, inventing and executing games (some of which are war related) with them. In fact, his keeping secret from Misra his engagement in "training for war" remains the most telling indication of his determination to realize his lost objects' mission.

Misra is not totally unaware of Askar's hostile disposition towards her, not necessary on account of her terrible temper during her painful monthly periods that earn Askar beatings for which Karin comes to take over the care of Askar but because of the conscious and unconscious outcomes of her being a non-Somali. Her accent affects Askar's articulation of some Somali sounds, and he (Askar) resents her speaking Amharic with Aw-Adan and he is bitter about the beatings he receives when learning a foreign language. He believes that "One is not beaten so harshly when one is learning in one's mother tongue" (Farah 88). Misra is scared of the passion with which Askar states his intention to deal with those who brutalize him (kill Aw-Adan and Quorrax), and she asserts "To avenge you're the kind that will drink his enemy's blood" (Farah 81). Nevertheless, Askar's hostility which is manifest in his declaration of intentions to kill and in his "dar[ing] Misra," pleading guilty to Misra's charge of vindictiveness do not really suggest that he is capable of killing anyone, even in a 
war situation. He likes water but blood unsettles him. Whenever he is angry he "feels blood in his mouth" and whenever scenes involving blood assail him in dreams he is unsettled. Besides, his most strident assertions about killing anyone must ultimately be viewed from the perspective offered in the following statement:

I don't know how long it was before I made the resolution that I had reached the point of human evolution where I could seriously plan to murder. Then something became obvious to me-or rather something was revealed to me-that I could kill, at least in thought. That was how I killed Uncle Quorrax and Aw-Aw-Adan out of the way and for whatever this is worth, declared them dead. And it was the first, but definitely not the last that, I tasted hate in my saliva-I tasted blood in my mouth, which is another manner of saying that I tasted someone else's death inside of me. (Farah 86)

All Askar's claims to murder amount to nothing more than his killing his enemies in thought or fantasy. He thrives on intellectual speculations, dreams, fantasies, imaginative creativities, emotional intensities and dialoguing multiple selfhoods, a reasonable number of which come into play at moments of crucial contemplation and action. Of course, these "forces at work within him" do always make it difficult, if not impossible, for him to murder anyone in a practical sense, even as a means to the achievement of his goal of making his lost objects come back to life- - a coming back to life which his complex search seems always to make him realize is possible only in thought.

If Askar can only "kill in thought" a person as heinous in his reckoning as AwAdan, then it follows that it is impossible for him to murder Misra who nurtured him and with whom he would always have some measure of emotional closeness. Askar's nationalistic commitment, to a great extent, remains emotional and intellectual despite his "desired" enlisting in the Somali Liberation Front. He is more interested in war games, training for war and intellectual discourse about war than the actual participation in war which must of necessity entail bloodshed. As the Kallafo men go to war and the Somali take territory from Ethiopia, Askar converts the room he shares with Misra into a war office, monitoring the Somali capture of territories and adjusting the map to reflect the gains; gains that make Askar and his fellow Somalis happy but which upset and destabilize Misra. Not only does Misra eventually declare that she is an Ethiopian at risk among the Somalis, she also refuses to allow Askar to accompany her to her supposed home in the "Highlands" because her people would kill him. She tells Askar, "One day you will identify yourself with your people [... ] you might even kill me to make your people's dream become a tangible reality" and Askar in real surprise responds, "One day, I might kill you" (Farah 99). Misra unmistakably establishes that their searches and lost objects are not only opposed but capable of resulting in the murder of each other. Askar, confronted by the bitter truth of the possibility of bloodshed in their relationship, comes to realize 
how flippant his previous declarations of intent to kill Misra are, since his association with blood all through Maps is that of "tasting blood in his mouth" whenever he is really upset or has a deep feeling of guilt. It is interesting to note that Misra is willing to return to Ethiopia without Askar when it did seem that the Somalis were winning the war but she stayed back as the tides changed. Moreover, it is ironic that when the Kallafo community became hostile to her, she did go to Mogadiscio in disguise to be with Askar; she even accepts to be a Somali citizen to save her neck. Her presence in Mogadiscio, especially after her indictment by Karin for the death of members of the Kallafo community, compounds Askar's internal conflicts. Hilaal's generosity and intellectual engagement with Askar on various topics and especially on the Kallafo community's accusation of Misra coupled with her desperate condition helped in making Askar accept Misra in spite of the confusion created in his mind by Karin's emotional testimonies. Askar's surprise at the disappearance of Misra from the hospital and his grief at her death, do not only make it improbable that he killed her, but also suggests that he is convinced that the retrieval of his lost objects is possible without the murder of Misra or anyone else. His arrest in connection with the murder of Misra is clearly premised on the policeman's remarks: "Do the names Misra, Aw-Adan, Qorrax and Karin mean anything to Askar? This is the question" (Farah 258). Of course, all these people have been part of Askar's life from the day he was born. And those he hated most he can kill only "'in thought." His sympathy for the Liberation Front remains only as a sympathy because he has not even filled the forms of the Liberation Front that will enable his admittance to its membership.

5

Thus, the two major characters' melancholia and fantasized quests for their personal and nationalistic lost objects continue right to the end of Maps. Misra's quest is terminated by death, but she remains "heroic" in her quest, tenaciously hanging on to her fantasies of lost identity and ideals. Her final "surrender" to the Somalis by "accepting" Somali citizenship is like one of those strategies she so well adopted to survive on other occasions but in Mogadiscio the strategy fails her. Askar's quest continues, even in police custody. He asks the question "Who is Askar?" (Farah 258) before his arrest but he also answers it under interrogation when he gives his name as "Askar Cali-Xamari" (Farah 259). His answer raises issues for which he seeks clarifications as he continues his quest in police custody. For instance, as he tells variants of the story of his foster mother, Misra's name takes on different variants in response to different circumstances. Moreover, it is in police custody that he assumes various roles in his struggle to understand the relationship he had and still has with Misra from different moral stances. Complex as this story is, it revolves around their melancholia which initiates and sustains their labyrinthine fantasized quests for the 
retrieval of their mirage-like lost objects. Accordingly, the two main characters are products of their internal complexes rather than their external reality. While they, like the other characters, are confronted with the same nationalist fervour, and the war it precipitates; their actions and inactions are different because of their unique personal experiences.

\section{Works Cited}

Brown, Michelle Lynn. "Bleeding for the mother (land): Reading testimonial bodies in Nurrudin Farah's Maps." Research in African Literatures 41.4 (2010): 125-43.

Butler, Judith. "Moral sadism and doubting one's own love: Kleinian reflections on melancholia." Reading Melanie Klein. Eds. Lyndsey Stonebridge and John Phillips. London: Routledge, 1998. 179-89.

Caputi, Mary. "The maternal metaphor in feminist scholarship." PoliticalPsychology 14.2 (1993): 309-29.

Chodorow, Nancy. The Reproduction of Mothering: Psychoanalysis and the Sociology of Gender. Berkley: U of California P, 1978.

Cobham, Rhonda. "Boundaries of the nation: Boundaries of the Self: African Nationalist fictions and Nurrudin Farah's Maps." Research in African Literatures 22.2 (1991): 83-98.

Eng, David L. “Melancholia/Postcoloniality: Loss in The Floating Life." Qui Parle 11.2 (1999): 137-50.

Epstein, Stephen. "Sexuality and identity: The contribution of Object Relations Theory to a constructionist Sociology." Theory and Society 20.6 (1991): 825-73.

Esonwanne, Uzoma. "The 'Crisis of the Soul': Psychoanalysis and African Literature." Research in African Literature 38.2 (2007): 140-42.

Farah, Nurrudin. Maps. 1986. New York: Penguin, 1999.

Freud, Sigmund. "Mourning and melancholia." The Standard Edition of the Complete Psychological Works of Sigmund Freud, Volume XIV (1914-1916): On the History of the Psycho-Analytic Movement, Papers on Metapsychology and Other Works. 1917. London: Hogarth Press, Institute for Psycho-Analysis, 1957. 23-58.

, Phillip Rieff. Character and Culture. New York: Collier Books,1963.

Jacobs, Amber. "The potential of theory: Melanie Klein, Luce Iragaray and the mother-daughter relationship. Hypatia 22.3 (2007): 175-93.

Klein, Melanie. Developments in Psychoanalysis. London: Hogarth Press, 1952.

. "Mourning and its relation to manic depressive states." Essential Papers on Object Loss. Ed. Rita V. Frankel. New York and London: New York U P, 1994.

Lerner, L. Scott. "Mourning and subjectivity: From Bersani to Proust, Klein, and Freud." Diacritics 37.1 (2007): 40-53.

Lewiecki-Wilson, Cynthia. Writing Against the Family: Gender in Lawrence and Joyce. Carbondale, IL: Illinois U P, 1994.

Ngaboh-Smart, Francis. "Nationalism and the aporia of national identity in Farah's Maps. Research in African Literatures 32.3 (2001): 86-102.

Stirling, Grant. "Neurotic narrative: Metafiction and Object-Relations Theory." College Literature 27.2 (2000): 80-102.

Sugnet, Charles. "Nuruddin Farah's Maps: Deterritorialization and 'The Postmodern.'” World Literature Today 72.4 (1998): 739-46.

Tettenborn, Eva. "Melancholia as resistance in contemporary African American Literature." Melus 31.3 (2006): 101-21.

Yahweh, Emmanuel. "The nation as a contested construct." Research in African Literatures 32.3 (2001): 45-56.

Wright, Derek "Parenting the nation: Some observations on Nurrudin Farah's Maps." College Literature 19/20.3/1(1992-1993): 176-84. 